\title{
Personnel Competence and Qualification Level Improvement: Motivation and Incentive Factors
}

\author{
Victoria I. Kirishchieva*
}

\begin{abstract}
Department of Economics, Accounting and Analysis, Rostov State Transport University, Rostov-on-Don 344038, Russia *Corresponding author. E-mail: milaya_vika@list.ru
\end{abstract}

\begin{abstract}
In modern business conditions, improvement of competence and qualification level of personnel, with the latter being one of the most important business resources, is a relevant issue. The impact on the given resource should be focused not only on managing it, but it should be primarily associated with the influences capable of ensuring an increase in their competence and qualification level. This consequently contributes to the achievement of strategic and tactical objectives of the enterprise. In this regard, motivation and incentive factors can be viewed as an effective tool for personnel management to encourage them to improve their competence and qualification level. The present work discusses and justifies the main factors of personnel motivation and incentive impact on their interest in improving their competence and qualification level. Based on the research results, workforce is divided into three categories depending on the influence of motivation and incentive factors.
\end{abstract}

Keywords: personnel, competence and qualification level, competencies, qualifications, motivation and incentive factors

\section{INTRODUCTION}

Nowadays, with global processes and intensification of production taking place, significant attention is focused on the problems of business development and its ability to adequately respond to economic changes. It is a common fact that the most effective workforce activating is the key factor for success in various fields. The personnel, representing the human capital of the enterprise, have a certain competence and qualification level, due to its intellectual component. Apart from "... enhancing the competitive performance of personnel, the development of workforce competencies facilitates competitiveness of the enterprise that attracts personnel of certain qualification for the accomplishment of production goals" [1].

Along with material and financial resources, an entity's personnel are one of the most important business resources. The impact on the given resource should be focused not only on managing it, but it should be primarily associated with the influences capable of ensuring an increase in their competence and qualification level. This consequently contributes to the achievement of strategic and tactical objectives of the enterprise. In this case, management of a business entity is able to appropriately respond to the changing conditions and take timely measures to transform the qualification structure of the business entity, to correctly identify the professional duties and capabilities of employees, and to promptly offer occupational training and retraining to the workforce. Increasing competence and qualification level of the workforce appears to be an indispensable condition for ensuring the effectiveness of the enterprise within its nondeterminate environment.

New technological solutions, modern scientific ideas and sufficiently favorable working conditions cannot provide a business entity with stable performance or successful work without well-trained and highly qualified personnel. In this regard, it is obvious that proper management of the personnel competence and qualification level increase is impossible without improving the determinants of workforce activating, forming the environment where employees' abilities develop and their qualification level rises.

The competence and qualification level of the workforce is determined by a number of factors, in particular:

- natural endowments, consequently affecting the individual's ability to improve their level of competence and qualifications;

- physical and psychological state of the individual, determining further interest in improving their competence and qualification level;

- potential knowledge and skills of a job seeker;

- degree of mastering theoretical knowledge and practical skills obtained in various educational institutions;

- interest in self-improvement and self-development throughout the professional life;

- the content and level of professional training provided by the management of the business entity during the individual's career;

- performance evaluation received by the employees during their professional lives;

- motivation and incentive system applied for the competence and qualification level improvement. 
This paper focuses on investigation and justification of financial incentive system in increasing the competence and qualification level of a business entity personnel.

\section{BASICS OF IMPROVING THE COMPETENCE AND QUALIFICATION LEVEL: MOTIVATION FACTORS}

Motivation and incentive factors for improving the competence and qualification level of the workforce.

On the current stage of economic development, motivation and incentive factors can be viewed as an effective tool for personnel management to encourage them to improve their competence and qualification level. In this regard, motivating and encouraging the workforce are necessary to increase the level of competence and qualification of the personnel and to achieve the target figures of a business entity.

In order to form an adequate system to motivate the workforce for energetic efforts in the field of improving their competence and qualification level, first of all, it is necessary to understand the employees' impetus in this process.

It is a matter of common knowledge that the motive is determined by a person's need and the necessity to meet it. According to the book "Motivation and Personality" by A. Maslow, "usually this term refers to the urge to satisfy a want, the desire to fill a certain vital need" [2]. The motivation for improving the competence and qualification level of the workforce can be determined by imposing this concept on the business entity's activity. In this context, the motive should be viewed as an impetus for employees to be involved in their competencies and qualifications improvement, as well as to encourage them to create and implement innovations, thus meeting the needs of selfdevelopment. As noted by F. Herzberg, B. Mosner, B. Bloch Sniderman in the work "The Motivation to Work", "it is natural for a person to look for ways of selfrealization in all areas of life, with work being among the most important ones" [3]. In light of this, the following chain of incentive elements, ensuring the workforce activating in their competence and qualification development, can be formed: the need for selfdevelopment and development of a business entity $\rightarrow$ motivating and encouraging the personnel $\rightarrow$ workforce activating to improve their competence and qualification level $\rightarrow$ development of the competencies and qualification level of the workforce $\rightarrow$ satisfaction of the employees' need for self-development.

As far as the personnel motivation is concerned, it should be noted that not all employees of a business entity can be offered the same motivation factors. The reason for this is that different employees have different motivational framework. Thus, at the business entity level, personnel with the motivation, related to the rewarding element of their work, can be distinguished. This particularly refers to the ability of employees to solve complex tasks. Every company also comprises materially driven employees. This factor is primarily related to remuneration. Furthermore, there are employees with balanced motivating needs.

Workforce motivation to increase their competence and qualification level should be implemented as a permanent process based on a systematic approach, which ensures sound personnel motivation management [4]. Moreover, different stages offer different sets of motives that depend on a large number of factors, both contributing to the creation of favorable conditions for creativity and hindering this process. The priority of motives can significantly alter under the influence of various positive and negative factors, since the socio-economic situation in the country changes over time, causing employee turnover and transformations in personnel needs, preferences and interests.

Workforce motivation should not be underestimated, as it can reduce further quality level of business processes. The effectiveness of competence motivation is determined by high wages, comfortable working conditions, communication, professional recognition, craving for achievements, meaningful and diverse job, engagement with work, and other factors.

\section{BASICS OF IMPROVING THE COMPETENCE AND QUALIFICATION LEVEL: INCENTIVE FACTORS}

The willingness of employees to continuously improve their skills and increase their level of competence should also be timely stimulated, since the personnel, seeking for permanent professional development, undoubtedly try to get financial rewards for their upgraded studies.

The key incentive principles affecting the workforce activity in improving their competence and qualification level and, as a result, the business entity development, can be reduced to the following:

- use of all possible motivation tools in the incentive system;

- differentiated approach to employee incentives based on their personal characteristics;

- adjustment of incentive conditions to changing external and internal factors;

- timely changing the incentives and their adaptation to current requirements.

In her work, M. S. Solovtsova suggests innovative approaches to improving the incentive system for academics in the Russian Federation, which can be fully transformed into the incentive system for workforce activating to improve their competence and qualification level:

- formation of an adaptive system of fixed salary payment, which takes into account the status of employees and their personal characteristics; 
- creating a bonus pay system based on personal approach to each employee, as well as on their individual performance;

- using an objective system of employee assessment and control for remuneration, with this system reflecting the dependence and interrelation of personnel performance with achievement of their goals.

The incentive system for the workforce activating to develop professionally should, first of all, be based on a fixed part of remuneration, but take into account the individual characteristics of employees and their ability to express fundamentally new investment and innovative ideas. An efficient remuneration system for employees can enhance their performance.

Together with the importance of salary in financial encouragement, a significant role is given to bonuses. The variable part of the employee's remuneration should include bonuses, compensations, fringe benefits and increments.

Interesting forms of encouragement are the stimulating work directions suggested by Akhmetzyanova A. U. [5], applicable to motivating employees to improve the level of competencies and qualifications, namely:

- motivation with free time, which consists in providing one workday to study documents, materials and scientific achievements in the sphere of employees' concern;

- training of employees at the expense of the employer, that will provide retaining of valuable employees in the company and their self-development;

- recognition of employees' high performance, including elements of moral encouragement and being a less expensive form in comparison with the above-mentioned ones;

- development of social programs at the enterprise, covering both the employee and his family members.

Obviously, in this issue financial encouragement is impossible to be the only focus. Moral encouragement also plays a considerable role. This type of incentive includes the following[7]:

- moral stimulation related to a person's need for professional recognition of their work, abilities, level of competence and qualification, and respect from the colleagues;

- social stimulation associated with a person's need for self-fulfilment and the desire to occupy a high position among the co-workers and society members;

- social and psychological stimulation based on a person's need for communication.

One of the incentive options lies in preparing and holding various contests and competitions, that reflect the competence and qualification level of the workforce. Moreover, the work on the implementation of moral incentives should be systematic [8]. A certain attention to this type of incentive will ensure not only the implementation of the business entity's activity to involve the workforce in the development of their competencies and qualifications, but also strengthening of the economic health of the enterprise as a whole. All of the above- mentioned directions of moral encouragement are aimed at workforce interest in professional self-development.

In the process of developing a moral encouragement system, the interests of all employees of the organization should be considered, since non-financial recognition differs depending on the employee's rank. In this regard, regular monitoring of personnel satisfaction with the moral encouragement system used at the enterprise is vital [9]. It will ensure the workforce needs analysis and result in their increasing interest in professional self-development. This moral encouragement system should be systematically adjusted and based on personnel surveys, since they are interested in the development of certain needs and can suggest the best changes in this system.

An efficient motivation and incentive system for a company's workforce aimed at enhancing their competence and qualification level provides the following advantages:

- growth of profits due to the recruitment of highlyqualified personnel;

- improvement of product quality, performed work, and provided services;

- active implementation of the latest scientific and technical achievements;

- recruitment of forward-thinking and skilled workforce;

- enhancing the efficiency and performance of personnel;

- reducing turnover of personnel, especially highlyqualified ones;

- improving the company's image.

\section{INTEGRATION OF MOTIVATION AND INCENTIVE FACTORS INTO THE STRUCTURE OF IMPROVEMENT OF THE PERSONNEL COMPETENCE AND QUALIFICATION LEVEL}

Depending on the impact of motivation and incentive factors on the workforce, all employees of a business entity can be roughly divided into three categories.

The first category is represented by the employees primarily focused on moral encouragement applied to them. This type of workforce consists of professionals in their branches of activity who, based on their competence and qualification level, are able to independently perform the employment functions assigned to them and achieve their goals. Furthermore, such employees can independently set goals within higher targeting and ensure their achievement by forming operational tasks. Workforce of this category can be either formed at the enterprise due to motivation and incentive factors, or can be recruited after reaching a certain level of competences and qualifications, with their interest to work in given organization, being supported by motivation and incentive system used in the company.

The second category consists of personnel equally driven by financial and moral encouragement. Due to their competencies and qualifications, the employees belonging 
to this category cannot work absolutely independently, make decisions, set goals and achieve them. In this case, managerial tasks lies in recurrent interaction with such employees to support them in achieving their goals. However, the personnel of this category still have the potential and desire to improve their competence and qualification level.

The third category comprises the workforce, primarily focused on financial encouragement. Such employees are basically unable to act independently regardless of the goals and objectives assigned to them. In this case, constant interaction with the manager, leading such employees through their career, is required; otherwise the work they are in charge of will not be performed. Personnel of this category usually belong to the lowest level of the business entity's organizational chart and have little interest in developing their competencies and qualifications.

\section{CONCLUSION}

Thus, there is a strong correlation between an employer's investment in the workforce professional development and the personnel commitment and efficiency. Therefore, the orientation and the incentive model applied at the business entity level will depend on the above-mentioned fact. A full-fledged creative process at the enterprise should be viewed as a constructive tool affecting not only the workforce inclination to improve their competence and qualification level, but as a final result of overall business activity.

\section{REFERENCES}

[1] Simonova M. V. Trends in Development of Competencies of HR Managers, “Upravlenie” Journal. - 2013. - No. 2 (2) - P. 100-103.

[2] Maslow A. Motivation and Personality, http://www.bim-bad.ru/docs/maslow

motivation_and_personality.pdf
[3] F. Herzberg et al., The Motivation to Work, translated by [D. A. Kulikov]. - M.: Vershina, 2007. -$240 \mathrm{p}$.

[4] Dolzhenko R. A. System Approach to Management of Labor Motivation of the Staff, Russian Journal of Entrepreneurship. - 2010. - Volume 11. - No. 8. - p. 70-75. - url: https://creativeconomy.ru/lib/6263.

[5] Solovtsova M. S. Innovative Approaches to Improve the Efficiency of the Personnel Labor Stimulation in the Higher Educational Institutions, "NAUKOVEDENIE" Online Journal, Volume 7, No. 5 (2015)

http://naukovedenie.ru/PDF/107EVN515.pdf (free access)

[6] Dubovskaya T. S. The Essence of Incentives Work Activity of Personnel, Eurasian Union of Scientists. 2016. No. 4 (25) P. 36-39

[7] Mandrazhi Z. R., Asanova Z. S. Main Directions of Improving the System of Moral Encouragement for Personnel, Scientific Observer of Taurida - 2016. - No. 2 (7). - P. 26-30.

[8] Surkova Yu. V. The Systemicity of Non-Monetary Labor Motivation at the Enterprise, Human Progress 2017. - Volume 3. - No. 10. -

https://cyberleninka.ru/article/n/sistemnostnematerialnogo-stimulirovaniya-truda-na-predpriyatii

[9] Ryabova M. A. Actual Problems of Creation of Effective System of Intangible Stimulation of Employees of Industrial Enterprises, Management of Economic Systems: Scientific Electronic Journal. 2017. - No. 4 (98). https://cyberleninka.ru/article/n/aktualnye-problemysozdaniya-effektivnoy-sistemy-nematerialnogostimlirovaniya-rabotnikov-promyshlennyh-predpriyatiy 